\title{
Genetic types and geochemical characteristics of natural gases in the Jiyang Depression, China
}

\author{
Wen-Tao Li $\cdot$ Yang Gao $\cdot$ Chun-Yan Geng
}

Received: 21 July 2014/Published online: 22 January 2015

(c) The Author(s) 2015. This article is published with open access at Springerlink.com

\begin{abstract}
Natural gases were widely distributed in the Jiyang Depression with complicated component composition, and it is difficult to identify their genesis. Based on investigation of gas composition, carbon isotope ratios, light hydrocarbon properties, as well as geological analysis, natural gases in the Jiyang Depression are classified into two types, one is organic gas and the other is abiogenic gas. Abiogenic gas is mainly magmatogenic or mantlederived $\mathrm{CO}_{2}$. Organic gases are further divided into coaltype gas, oil-type gas, and biogas according to their kerogen types and formation mechanisms. The oil-type gases are divided into mature oil-type gas (oil-associated gas) and highly mature oil-type gas. The highly mature oil-type gases can be subdivided into oil-cracking gas and kerogen thermal degradation gas. Identification factors for each kind of hydrocarbon gas were summarized. Based on genesis analysis results, the genetic types of gases buried in different depths were discussed. Results showed that shallow gases $(<1,500 \mathrm{~m})$ are mainly mature oil-type gases, biogas, or secondary gases. Secondary gases are rich in methane because of chromatographic separation during migration and secondary biodegradation. Secondary biodegradation leads to richness of heavy carbon isotope ratios in methane and propane. Genesis of middle depth gases $(1,500-3,500 \mathrm{~m})$ is dominated by mature oil-type gases.
\end{abstract}

\section{W.-T. Li}

School of Energy Resources, China University of Geosciences, Beijing 100083, China

W.-T. Li · Y. Gao $(\bowtie) \cdot$ C.-Y. Geng

Geoscience Research Institute, Shengli Oilfield Company

SINOPEC, Dongying 257015, Shandong, China

e-mail: swap124@163.com

Edited by Jie Hao
Deep gases $(3,500-5,500 \mathrm{~m})$ are mainly kerogen thermal degradation gas, oil-cracking gas, and coal-type gas.

Keywords Genetic types - Natural gases - Jiyang Depression · Light hydrocarbon properties · Carbon isotope ratios $\cdot$ Identification factors

\section{Introduction}

The Jiyang Depression is located in the north part of Shandong Province in China, on the fluvial plain and the delta where the Huanghe River runs into the Bohai Sea. Tectonically, the Jiyang Depression is located in the southeast part of the Bohai Bay Basin. It is a big terrestrial depression and ranks as one of the most prolific petroliferous area ( $\mathrm{Li}$ et al. 2003). Since the discovery of the Shengli Oilfield in 1960 , $50 \times 10^{8} \mathrm{t}$ of OOIP and $2,500 \times 10^{8} \mathrm{~m}^{3}$ OGIP have been proved, at the same time, $10.7 \times 10^{8}$ tons of oil and $460 \times 10^{8} \mathrm{~m}^{3}$ gases have been produced.

Five sets of source rocks were developed in the Jiyang Depression, and they are distributed in the CarboniferousPermian, the second member of the Kongdian Formation $\left(E_{2}\right)$, and the fourth, third, and first members of the Eogene Shahejie Formation $\left(\mathrm{Es}_{4}, \mathrm{Es}_{3}\right.$, and $\left.\mathrm{Es}_{1}\right)$. The kerogen in those source rocks is mainly sapropelic type, and some of them are humic type. After a series of tectonic movements, these source rocks vary greatly in depth and evolution histories which influence gas generation and accumulation in many aspects, such as gas components, genesis, etc. (Zhang 1991). Thirteen commercial gas bearing layers have been discovered in the Neogene Minghuazhen and Guantao Formations, the Eogene Shahejie Formation, and the Paleozoic Carboniferous-Permian and Ordovician in the Jiyang Depression (Fig. 1). Gas reservoirs occurred widely at a depth from 192 
to $4,750 \mathrm{~m}$. In these reservoirs, gas compositions vary greatly from hydrocarbon gas to abiogenic gas. As for hydrocarbon gas, the paraffin hydrocarbon composition and carbon isotope ratios varied dramatically. There are several different genesis models such as oil-type gas, coal-type gas, biogas, and inorganic mantle source gas, etc. (Gao et al. 2011; Zhou 2004; Luo et al. 2008). Natural gases usually occur as normal gas reservoirs, tight sandstone gas reservoirs, shale gas reservoirs, and coal-bed methane.

To make a thorough investigation of the gas genesis in the Jiyang Depression, the authors collected abundant data from exploration wells with commercial gas flow including 472 sets of natural gas composition data, 293 sets of carbon isotope ratio data (both hydrocarbon gas and carbon dioxide), and 69 sets of light hydrocarbon properties data (Fig. 2). According to gas component contents, carbon isotope ratios and light hydrocarbon properties, combined with geological analysis, natural gases in the Jiyang Depression are divided into two categories namely organic gas and abiogenic gas. Organic gas was further divided into coal-type gas, oil-type gas, and biogas according to kerogen type and formation mechanism. The oiltype gases were finally divided into mature oil-type gas (oilassociated gas) and highly mature oil-type gas (including oilcracking gas and kerogen thermal degradation gas) (Schoell 1980). The geochemical properties of each kind of natural gas were discussed, respectively.

\section{Abiogenic gas}

Abiogenic gas in the Jiyang Depression is mainly $\mathrm{CO}_{2}$, and its distribution is controlled by great deep faults (Tang
Fig. 1 Strata histogram and gas bearing layers in the Jiyang Depression

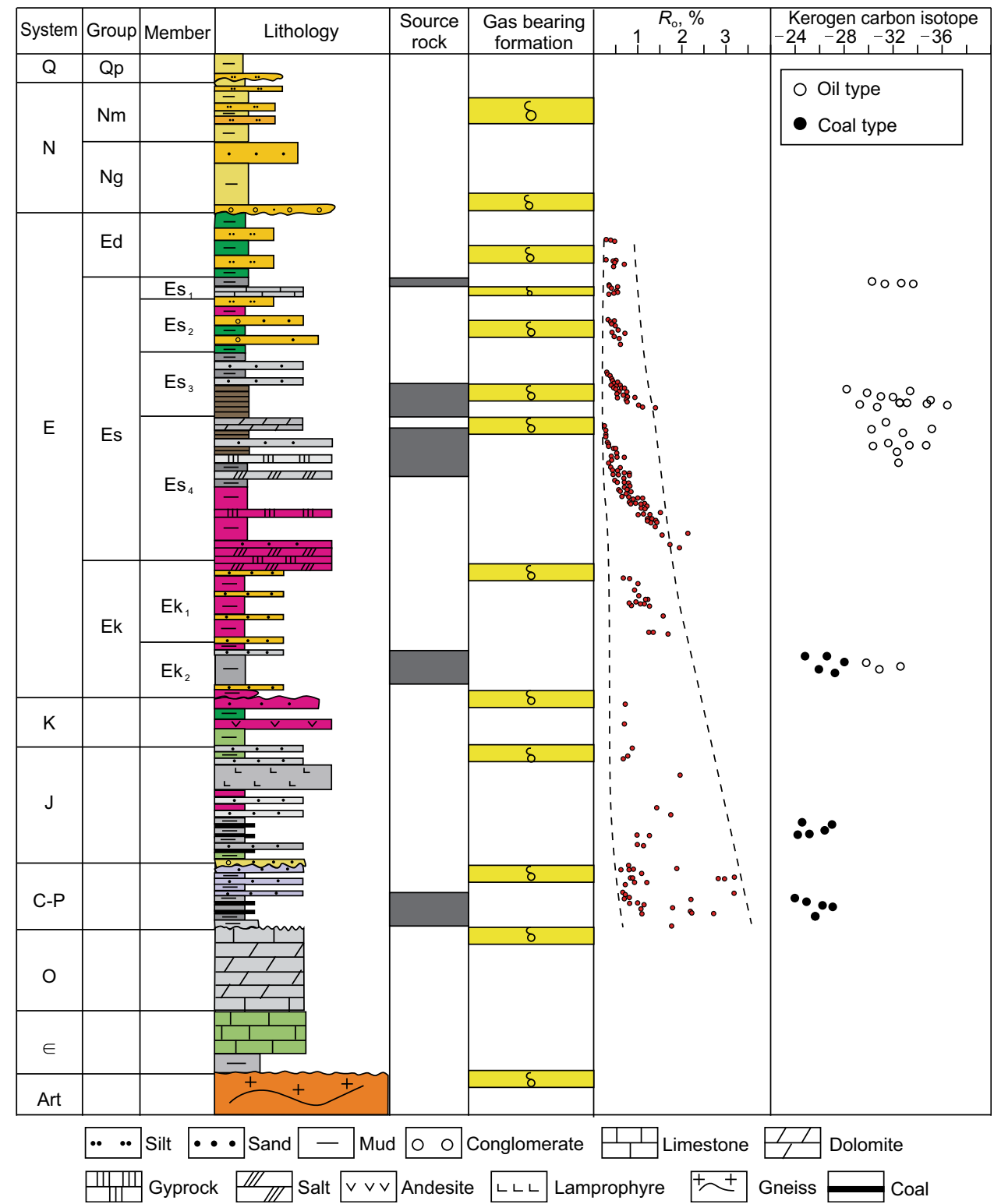


Fig. 2 Structural framework and typical gas producing wells in the Jiyang Depression

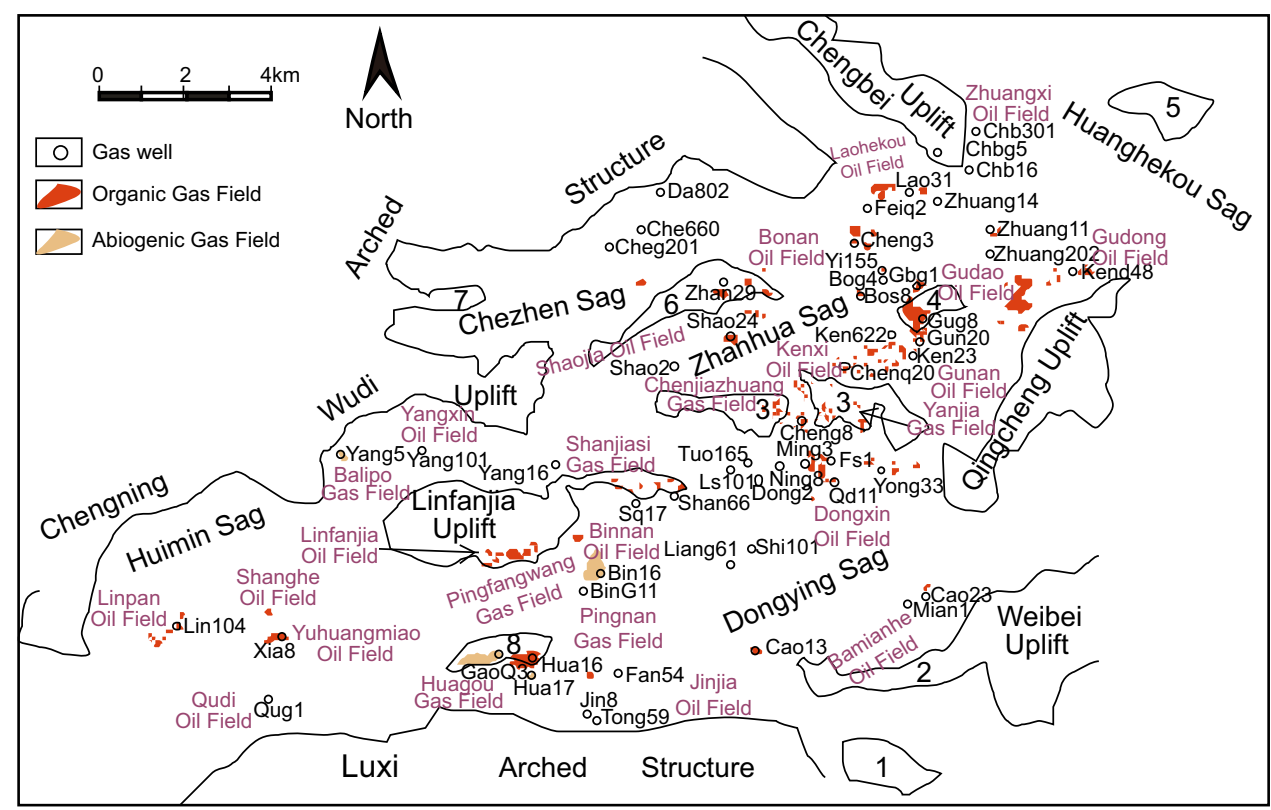

1-Shouguang Uplift; 2-Guangrao Uplift; 3-Chenjiazhuang Uplift; 4-Gudao Uplift; 5-Bonan Uplift; 6-Yihezhuang Uplift; 7-Qingyun Uplift; 8-Gaoqing Uplift; et al. 2002). This type of gas is mainly found in Pingfangwang, Pingnan, and Huagou gas fields in the western part of the Dongying Sag and the Balipo gas field in the northern part of the Huimin Sag. Vertically, $\mathrm{CO}_{2}$ is mainly distributed in the Shahejie Formation of Eogene (Es for short), Neogene, and Ordovician. The $\mathrm{CO}_{2}$ content of such reservoirs ranges from $55.5 \%$ sto $100 \%$ and averages $82.4 \%$. Hydrocarbon gases were mixed into $\mathrm{CO}_{2}$ reservoirs in varying degrees. The methane content in those reservoirs ranges from $0 \%$ to $37.2 \%$ with an average of $13.3 \%$, while the heavy hydrocarbon $\left(\mathrm{C}_{2+}\right)$ content was low with an average value of $1.4 \%$ (Table 1).

There are usually three genetic types of natural $\mathrm{CO}_{2}$, namely magma degassing, decomposition of carbon rich crustal rock, and decomposition of organic matter. Studies have confirmed that $\delta^{13} \mathrm{C}_{\mathrm{CO} 2}$ can be used to identify its genesis. It is generally believed that $\delta^{13} \mathrm{C}_{\mathrm{CO} 2}>-8 \%$ indicates inorganic genesis, and $\delta^{13} \mathrm{C}_{\mathrm{CO} 2}<-10 \%$ indicates organic genesis (Zhang 1991; Dai 1993). In the Jiyang Depression, gas reservoirs with high $\mathrm{CO}_{2}$ content ( $>60 \%$ ) usually have heavy carbon isotope ratios ranging from $-9.8 \%$ to $-3.4 \%$ (PDB). The $\delta^{13} \mathrm{C}_{\mathrm{CO} 2}$ of most samples was higher than $-7 \%$, and this can be classified as inorganic genesis. The $\mathrm{CO}_{2}$ content in hydrocarbon gas reservoirs was usually lower than $10 \%$ with $\delta^{13} \mathrm{C}_{\mathrm{CO} 2}$ less than $-8 \%$, and it can be deduced that the $\mathrm{CO}_{2}$ came from decarboxylation of organic matter (Fig. 3).

Previous studies have shown that helium of different genesis has different isotopic compositions, and the ${ }^{3} \mathrm{He} /{ }^{4} \mathrm{He}$ values of atmosphere, earth mantle, and crust are, respectively, $1.4 \times 10^{-6}, 1.1 \times 10^{-5}$, and $2 \times 10^{-8}$ (Sun et al. 1996). As shown in Table 2 , the ${ }^{3} \mathrm{He} /{ }^{4} \mathrm{He}$ value of $\mathrm{CO}_{2}$ reservoirs in the Pingfangwang, Huagou, and Yangxin gas fields in the Jiyang Depression was high (3.55-4.49 $\left.\times 10^{-6}\right)$, and $\mathrm{R} / \mathrm{Ra}$ was $2.5-3.2$, indicating a mixed He origin of mantle genesis and crust genesis (Wang et al. 2013). The isotopic analysis of rare gases and $\mathrm{CO}_{2}$ indicated that the highly concentrated $\mathrm{CO}_{2}$ gas reservoir in the Jiyang Depression originated from magma-mantle degassing (Hunt et al. 2012).

\section{Organic gases}

Organic hydrocarbon gases are produced from sedimentary organic matter due to a series of biological-geochemical reactions. Organic matter of different types and in different thermal evolution stages will produce hydrocarbon gases with different component compositions and isotopic compositions. $\mathrm{C}_{1} / \mathrm{C}_{1-5}$ and $\delta^{13} \mathrm{C}_{1}$ of hydrocarbon gases in the Jiyang Depression changed regularly with depth, and could be divided into three categories according to the reservoir depth (Fig. 4):

(1) Buried less than $1,500 \mathrm{~m}$ : the $\mathrm{C}_{1} / \mathrm{C}_{1-5}$ value is usually high and ranges from $0.8 \%$ to $1.0,90 \%$ of the natural gases are dry gas $\left(\mathrm{C}_{1} / \mathrm{C}_{1-5}>0.95\right)$ with a methane content more than $95 \%$, while the values of $\delta^{13} \mathrm{C}_{1}$ can be separated into two groups: the values of group one are between $-40 \%$ and $-50 \%$, and the values of group two are less than $-55 \%$. 
Table 1 Geochemical characteristics of $\mathrm{CO}_{2}$ in the Jiyang Depression

\begin{tabular}{|c|c|c|c|c|c|c|c|c|c|}
\hline Area & Well & Formation & Depth, m & $\begin{array}{l}\delta^{13} \mathrm{C}_{\mathrm{CO} 2}, \% o \\
(\mathrm{PDB})\end{array}$ & $\begin{array}{l}\delta^{13} \mathrm{C}_{1}, \% o \\
(\mathrm{PDB})\end{array}$ & $\mathrm{CH}_{4}, \%$ & $\mathrm{C}_{2+}, \%$ & $\mathrm{~N}_{2}, \%$ & $\mathrm{CO}_{2}, \%$ \\
\hline \multirow[t]{9}{*}{ Pingfangwang Gas Field } & Bin1 & $\mathrm{E}$ & 1890.0-1898.0 & -6.1 & -45.8 & 3.53 & 2.09 & 0 & 94.13 \\
\hline & Ping13-2 & $\mathrm{E}$ & $1453.6-1483.2$ & -4.7 & -52.7 & 26.43 & 2.79 & 1.07 & 68.85 \\
\hline & Ping13-4 & $\mathrm{E}$ & $1450.8-1486.4$ & -4.4 & -51.7 & 19.04 & 4.85 & 1.21 & 74.92 \\
\hline & Ping14-3 & $\mathrm{E}$ & $1467.0-4684.6$ & -4.3 & -51.8 & 18.17 & 3.30 & 0.61 & 77.93 \\
\hline & Ping4 & $\mathrm{E}$ & $1459.4-1461.4$ & -5.4 & -50.9 & 20.89 & 3.33 & 0.46 & 75.33 \\
\hline & Ping9-3 & $\mathrm{E}$ & $1462.6-1489.2$ & -4.5 & -51.6 & 22.46 & 3.40 & 0.25 & 73.87 \\
\hline & Pingq12 & $\mathrm{E}$ & $1470.5-1472.5$ & -4.4 & -51.9 & 21.63 & 3.39 & 0.63 & 74.2 \\
\hline & Pingq12-61 & $\mathrm{E}$ & $1452.4-1487.6$ & -4.5 & -51.8 & 17.13 & 3.19 & 0.38 & 79.17 \\
\hline & Pingq4 & $\mathrm{E}$ & $1459.4-1474.5$ & -5.4 & -51.7 & 20.89 & 3.32 & 0.46 & 75.33 \\
\hline \multirow[t]{2}{*}{ Pingnan Gas Field } & Bin11 & $\mathrm{E}$ & $1980.2-2250.0$ & -5.9 & -47.6 & 1.31 & 1.06 & 0 & 97.31 \\
\hline & Bing11 & $\mathrm{O}$ & $2301.0-2307.0$ & -6.3 & -47.6 & 1.52 & 0.74 & 0.25 & 97.06 \\
\hline \multirow[t]{3}{*}{ Binnan Oilfield } & $\operatorname{Bin} 4$ & $\mathrm{E}$ & $1510.0-1568.0$ & -9.8 & -49.4 & 32.62 & 4.91 & 0 & 60.72 \\
\hline & Bin4-13-1 & $\mathrm{E}$ & $1453.0-1455.0$ & -5.1 & -52.4 & 22.71 & 3.76 & 0.85 & 72.68 \\
\hline & Bin4-6-6 & $\mathrm{E}$ & $1469.7-1474.7$ & -4.6 & -51.7 & 23.52 & 3.53 & 0.33 & 72.5 \\
\hline \multirow[t]{5}{*}{ Huagou Gas Field } & Gao10 & $\mathrm{N}$ & $824.3-838.9$ & -5.2 & & 0 & 0 & 0 & 99.99 \\
\hline & Gao3 & $\mathrm{N}$ & $833.4-834.8$ & -4.4 & -35 & 0.07 & 0 & 0 & 97.87 \\
\hline & Gao53 & $\mathrm{N}$ & $811.4-818.0$ & -6.8 & & 0.04 & 0 & 0 & 99.96 \\
\hline & Hua17 & $\mathrm{E}$ & $1965.1-1980.0$ & -3.4 & -54.39 & 7.47 & 0.51 & 2.05 & 89.70 \\
\hline & Hua17 & $\mathrm{E}$ & 2000.0-2009.6 & -3.4 & -54 & 10.99 & 0.35 & 9.03 & 79.56 \\
\hline \multirow[t]{2}{*}{ Balipo Gas Field } & Yang25 & $\mathrm{E}$ & 2793.9-2805.0 & -4.4 & -42.51 & 0.52 & 0 & 3.83 & 95.64 \\
\hline & Yang5 & $\mathrm{O}$ & $2380.4-2386.0$ & & & 0.76 & 0 & 0 & 99.24 \\
\hline
\end{tabular}

E Eogene, N Neogene, O Ordovician

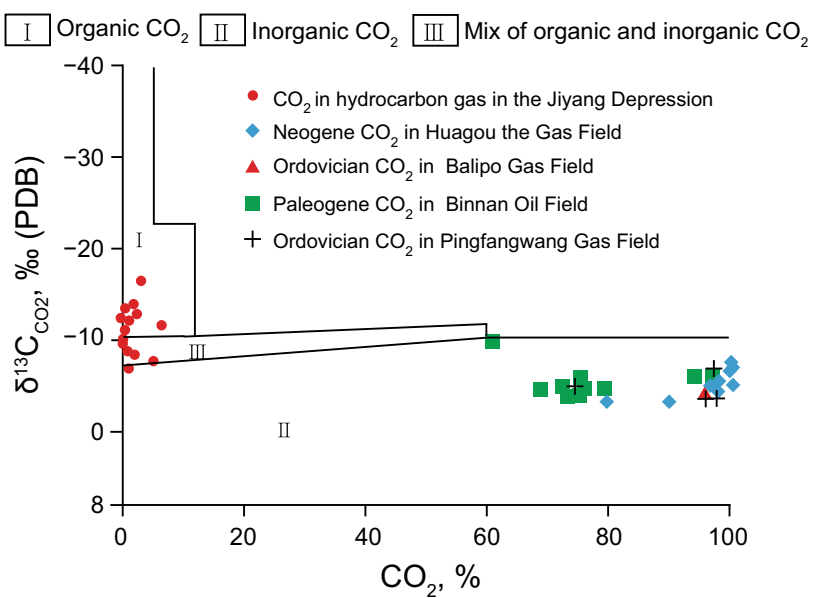

Fig. 3 Identifying inorganic and organic $\mathrm{CO}_{2}$ with $\delta^{13} \mathrm{C}_{\mathrm{CO} 2}-\mathrm{CO}_{2}$ relationships (Dai 1993)

(2) Buried between 1,500 and 3,500 m: the heavy hydrocarbon content is usually high, and $\mathrm{C}_{1} / \mathrm{C}_{1-5}$ ranges from 0.4 to 0.9 . Most gases are associated with oil, and their $\delta^{13} \mathrm{C}_{1}$ ranges from $-45 \%$ to $-52 \%$.

(3) Buried between 3,500 and 5,500 m: the value of $\mathrm{C}_{1} /$ $\mathrm{C}_{1-5}$ ranges from 0.6 to 1.0. Compared with the natural gas buried between 1,500 and $3,500 \mathrm{~m}$, the value of $\mathrm{C}_{1} / \mathrm{C}_{1-5}$ is higher, and the $\delta^{13} \mathrm{C}_{1}$ is also heavier with a value of $-30 \%$ to $-50 \%$.

The carbon isotope composition can be used to determine the natural gas genesis as concluded below. Under conditions of similar maturity, hydrocarbon gases generated from sapropelic-type kerogen usually had heavier $\delta^{13} \mathrm{C}_{1}$ than gases generated from humic kerogen; under the condition of similar kerogen type, the natural gases of high thermal evolution degree tend to have heavy $\delta^{13} \mathrm{C}_{1}$. Due to multiple reasons such as various kerogen types, different thermal evolution degrees, and secondary changes, the distribution characteristics of $\delta^{13} \mathrm{C}_{1}$ show that $\delta^{13} \mathrm{C}_{1}$ values of natural gases at middle depth are much lower, but those at shallow and deep depths are higher (Fig. 4).

To identify the genesis of natural gases, the three categories of natural gases (shallow gas $<1,500 \mathrm{~m}$, middle gas $1,500-3,500 \mathrm{~m}$, and deep gas $>3,500 \mathrm{~m}$ ) were put into the genesis identification template built by Dai (1993). As shown in Fig. 5, the genesis of shallow gas is complicated with biogas and oil-associated gas dominating, while there is still a small portion of shallow gas having a $\delta^{13} \mathrm{C}_{1}$ value of $-40 \%$ to $-55 \%$ with high $\mathrm{C}_{1} / \mathrm{C}_{1-5}$ and $\mathrm{C}_{1} / \mathrm{C}_{2+3}$ values higher than 500 , which indicate secondary changes. 
Table 2 Characteristics of rare gas isotope in $\mathrm{CO}_{2}$ gas reservoirs in the Jiyang Depression

\begin{tabular}{lllllrr}
\hline Area & Well & Depth, m & ${ }^{3} \mathrm{He} /{ }^{4} \mathrm{He}, 10^{-8}$ & $\mathrm{R} / \mathrm{Ra}$ & ${ }^{40} \mathrm{Ar} /{ }^{36} \mathrm{Ar}$ & ${ }^{4} \mathrm{He} /{ }^{20} \mathrm{Ne}$ \\
\hline Binnan Oilfield & Bin4-6-6 & $1469.7-1474.7$ & 387 & 2.76 & 3.18 & 7,791 \\
Huagou Gas Field & Hua17 & $1965.1-1980$ & 445 & 3.18 & 1,054 \\
& Hua17 & $2000-2009.6$ & 449 & 2.56 & 1,220 \\
Pingfangwang Gas Field & Ping13-2 & $1453.6-1483.2$ & 359 & 2.54 & 1,722 \\
& Ping13-4 & $1450.8-1486.4$ & 355 & 3.19 & 1,378 \\
& Ping14-3 & $1467-1484.6$ & 447 & 2.76 & 317 & 110 \\
& Ping9-3 & $1462.6-1489.2$ & 387 & 2.75 & 1,051 \\
& Pingq12 & $1470.5-1472.5$ & 385 & 2.58 & 1,478 \\
Yangxin Oilfield & Pingq12-61 & $1452.4-1487.6$ & 361 & 2.75 & 1,758 \\
\hline
\end{tabular}

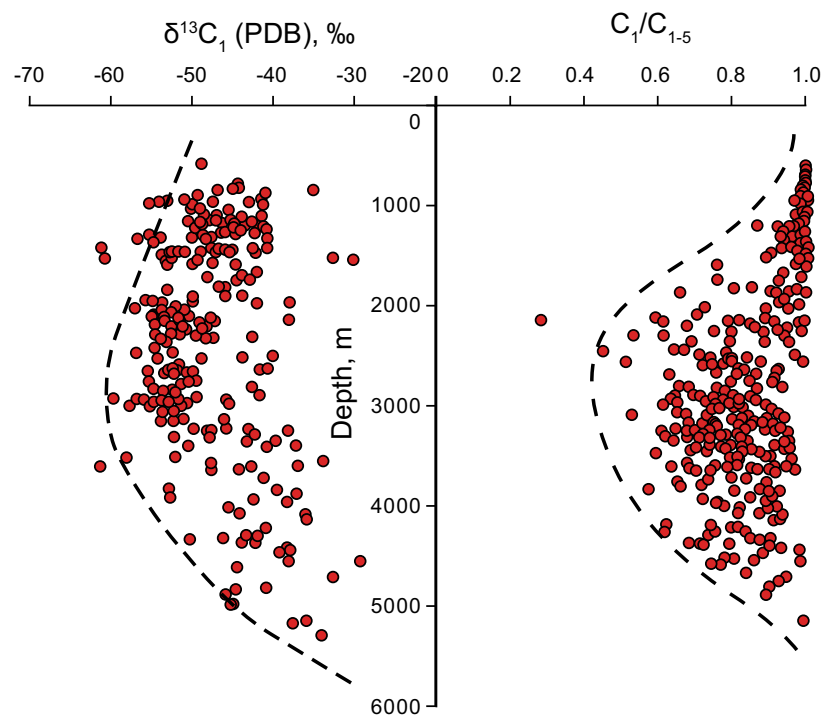

Fig. 4 Variation of $\delta^{13} \mathrm{C}_{1}$ and $\mathrm{C}_{1} / \mathrm{C}_{1-5}$ of hydrocarbon gases with depth in the Jiyang Depression

The genesis of middle gas is comparatively simple and dominated by oil-associated gas. As for deep gas, there are several genesis options such as highly mature oil-cracking gas, associated gas with condensate oil, coal-type gas, and the mixture of two or more of them (Fig. 5).

Carbon isotope ratios of methane, ethane, and propane can also be used to identify the genesis of natural gases (Lin et al. 2011). As shown in Fig. 6, shallow buried hydrocarbon gases in the Jiyang Depression were located in the area of oil-associated gas, but the ethane and propane carbon isotope ratios of some samples were abnormally heavy, which might be caused by secondary changes such as biodegradation. The middle buried hydrocarbon gases are mainly oil-associated gas mixed with a small amount of coal-type gas. The deep natural gases were coal-type gas, oil-type gas, as well as a mixture of the both.
In general, hydrocarbon gases in the Jiyang Depression include biogas, oil-associated gas, highly mature oil-type gas, coal-type gas, and their geochemical characteristics are separately discussed below.

\subsection{Biogas}

Biogas is defined as hydrocarbon gas or nonhydrocarbon gas that is produced due to biochemical reactions of fermentative bacteria and methanogens in the process of degradation of organic matter in source rocks or crude oil (Gao et al. 2010). Naturally existed biogas was formed due to two kinds of processes: one is methyl-type fermentation $\left(\mathrm{CH}_{3} \mathrm{COOH} \rightarrow \mathrm{CH}_{4}+\mathrm{CO}_{2}\right)$ and the other is carbonate reduction $\left(\mathrm{CO}_{2}+4 \mathrm{H}_{2} \rightarrow \mathrm{CH}_{4}+2 \mathrm{H}_{2} \mathrm{O}\right)$. Limited by the survival temperature of methanogens $\left(0-75^{\circ} \mathrm{C}\right)(\mathrm{Li}$ et al. 2008), biogas was mainly developed in shallow-middle buried horizons. The present geothermal gradient in the Jiyang Depression is about $3{ }^{\circ} \mathrm{C} / 100 \mathrm{~m}$, and the surface temperature was about $17{ }^{\circ} \mathrm{C}$, so biogas in the Jiyang Depression tends to occur above 2,000 m. Biogas reservoirs have already been discovered and they are scattered in the Huagou and Yangxin gas fields.

The composition of biogas is fairly simple and is mainly methane. Heavy hydrocarbon $\left(\mathrm{C}_{2+}\right)$ contents are extremely low (usually less than $0.5 \%$ ), the value of $\mathrm{C}_{1} / \mathrm{C}_{1-5}$ is higher than 0.995 , and there are also low levels of nonhydrocarbon components (mainly $\mathrm{N}_{2}, \mathrm{CO}_{2}$ ). $\delta^{13} \mathrm{C}_{1}$ ranged from $-55 \%$ to $-60.9 \%$ (Table 3 ) (Hu et al. 2010). Since very little ethane and propane exist in biogas, it is difficult to measure their corresponding carbon isotope ratios.

Biogas is mainly developed in the first member of the Eogene Shahejie Formation (Es $s_{1}$ for short) in the Yangxin and Huagou gas fields. Source rocks in $\mathrm{Es}_{1}$ were buried in less than 2,000 $\mathrm{m}$, and were at an immature stage with an $R_{\mathrm{O}}$ value of $0.3 \%-0.6 \%$, the formation temperature was about $55-75{ }^{\circ} \mathrm{C}$, which provided favorable conditions for 
Fig. 5 Genesis identification template for hydrocarbon gas in the Jiyang Depression (Dai 1993)

Fig. 6 Characteristics of $\delta^{13} \mathrm{C}_{1}$, $\delta^{13} \mathrm{C}_{2}$, and $\delta^{13} \mathrm{C}_{3}$ in the Jiyang Depression (Dai 1993)
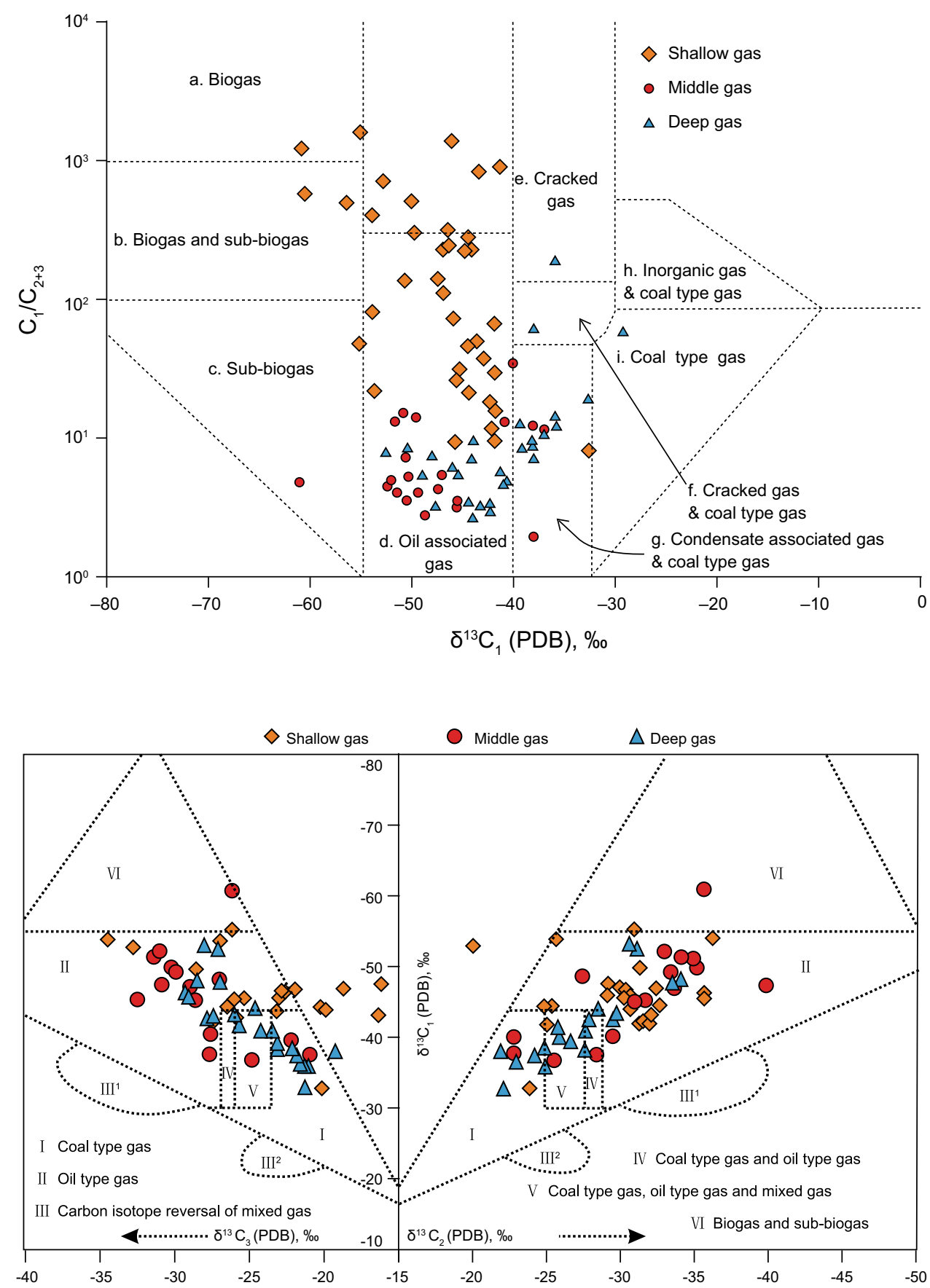

Table 3 Geochemical properties of biogas in the Jiyang Depression

\begin{tabular}{lllllllllll}
\hline Area & Formation & Well & Depth, $\mathrm{m}$ & $\mathrm{CO}_{2}, \%$ & $\mathrm{~N}_{2}, \%$ & $\mathrm{CH}_{4}, \%$ & $\mathrm{C}_{2+}, \%$ & $\delta^{13} \mathrm{C}_{1}, \%(\mathrm{PDB})$ \\
\hline Yangxin Gas Field & $\mathrm{Es}_{1}$ & Yang101 & $1504.2-1529.6$ & 0.39 & 1.04 & 98.4 & 0.17 & -60.6 \\
& $\mathrm{Es}_{1}$ & Yang16 & $1319.0-1325.0$ & 2.98 & 2.17 & 94.66 & 0.19 & -56.5 \\
& $\mathrm{Es}_{1}$ & Yang21 & $1412.0-1415.6$ & 0.1 & 1.69 & 97.16 & 0.08 & -60.9 \\
Huagou Gas Field & $\mathrm{Es}_{1}$ & Hua4 & $1276.0-1307.0$ & 0.17 & 7.38 & 89.25 & 0.17 & -55.4 & 0.14 & -55.0 \\
& $\mathrm{Es}_{1}$ & Hua171 & 1453.0 & 13.9 & 6.68 & 79.10 & 0 \\
\hline
\end{tabular}


survival of methanogens. Anaerobes and methanogens have already been detected in the formation water in this area, and this confirmed that natural gas occurring in this interval is biogas.

\subsection{Mature oil-type gas (oil-associated gas)}

Mature oil-type gas is generated by sapropelic-type source rocks in mature stage $\left(R_{\mathrm{o}}=0.6 \%-1.3 \%\right)$. Since sapropelic-type source rocks tended to generate more oil than gas during its mature stage, this kind of gas usually occurred as dissolved gas in oil reservoirs. Sometimes gas would exsolve from oil due to changes in temperature and pressure, and a gas cap would be formed.

Mature oil-type gas is the most important kind of natural gas in the Jiyang Depression. Most shallow gases and middle gases as well as part of deep gases are of this kind, and the reserves of this kind of gas resource account for $3 / 4$ of all the proved gas reserves in place. Mature oil-type gas usually occurred in the third member and the fourth member of the Eogene Shahejie Formation $\left(\mathrm{Es}_{3}, \mathrm{Es}_{4}\right)$, and sometimes in buried hills in the Paleozoic Carboniferous or Ordovician (e.g., Zhuangxi Oilfield). This kind of gas always occurred associated with oil reservoirs and gas was produced together with oil.

The methane content of mature oil-type gas varied greatly and ranged from $25.6 \%$ to $99.6 \%$. The methane content of most oil-associated gas $(81 \%)$ was about $60 \%-90 \%$, the heavy hydrocarbon content ranged from $0 \%$ to $70.9 \%$, and $C_{1} / C_{1-5}$ ranged from 0.6 to 0.99 . $\delta^{13} C_{1}$ of mature oil-type gas in the Jiyang Depression ranged from $-38 \%$ to $-55 \%, \delta^{13} \mathrm{C}_{2}$ ranged from $-26.3 \%$ to $-34.9 \%, \delta^{13} \mathrm{C}_{3}$ ranged from $-25.6 \%$ to $-32.1 \%$, $\delta^{13} \mathrm{C}_{4}$ ranged from $-25.6 \%$ to $-32.1 \%$, and they were arranged in the order of $\delta^{13} \mathrm{C}_{1}<\delta^{13} \mathrm{C}_{2}<\delta^{13} \mathrm{C}_{3}<\delta^{13} \mathrm{C}_{4}$ (Table 4).

$\delta^{13} \mathrm{C}_{1}$ and $\delta^{13} \mathrm{C}_{2}$ of mature oil-type gas in the Jiyang Depression correlated well with depth, so it is possible to calculate the maturity using gas carbon isotope ratios. Comparison between gas samples and source rock samples was carried out, and the relationship between $\delta^{13} \mathrm{C}_{1}$ and $R_{\mathrm{o}}$ was established:

$\delta^{13} \mathrm{C}_{1}=6.942 \ln R_{\mathrm{o}}-45.254\left(R_{\mathrm{o}}=0.4-1.3\right)$,

where $\delta^{13} \mathrm{C}_{1}$ is the methane carbon isotope ratios of mature oil-type gas, $\% ; R_{\mathrm{o}}$ is vitrinite reflectance, $\%$.

\subsection{Highly mature oil-type gas}

Highly mature oil-type gas was generated by sapropel-type source rock in highly mature stage $\left(R_{\mathrm{O}}>1.3 \%\right)$ (Zhao et al. 2013). There are two options for the genesis of highly mature oil-type gas, one is kerogen thermal degradation gas which means that sapropel-type kerogen degrades into natural gas at high temperature; and the other is oilcracking gas which means that oil cracks into natural gas at high temperature (Lu et al. 2006).

Compared with mature oil-type gas, kerogen thermal degradation gas usually has a higher value of $\mathrm{C}_{1} / \mathrm{C}_{1-5}$, and heavier $\delta^{13} \mathrm{C}_{1}$ and $\delta^{13} \mathrm{C}_{2}$. Methane comprises $70.78 \%-88.6 \%$ of kerogen thermal degradation gas and heavy hydrocarbons about $5 \%-29 \%$, usually in the range of $10 \%-15 \%$. The value of $\mathrm{C}_{1} / \mathrm{C}_{1-5}$ ranged from 0.7 to 0.9 and was a little higher than that of mature oil-type gas. $\delta^{13} \mathrm{C}_{1}$ ranged from $-43.9 \%$ to $-33.9 \%, \delta^{13} \mathrm{C}_{2}$ ranged from $-27.6 \%$ to $-28.7 \%, \delta^{13} \mathrm{C}_{3}$ ranged from $-23.3 \%$ to $-25.9 \%$, and $\delta^{13} \mathrm{C}_{4}$ ranged from $-25.0 \%$ o to $-26.6 \%$. There was an apparent reversal of $\delta^{13} \mathrm{C}_{3}$ and $\delta^{13} \mathrm{C}_{4}$ (Table 5). There are multiple reasons for the isotope reversal such as mixture of gases from different kerogen types, mixture of gases from the same kerogen type but of different maturities, inorganic originated hydrocarbon gas, and biodegradation gas (Burruss and Laughrey 2010). Analysis of the reservoir forming processes indicated that the discovered highly mature oil-type gases originated from the same source rocks, i.e., the fourth member of the Eogene Shahejie Formation $\left(\mathrm{Es}_{4}\right)$, which was deeply buried with little chance of undergoing biodegradation. Therefore, it can be inferred that the reversal in $\delta^{13} \mathrm{C}_{3}$ and $\delta^{13} \mathrm{C}_{4}$ was caused by the mixing of gases of different maturities.

Only oil-cracking gas was discovered in the Minfeng area (Chen et al. 2014), where the fourth member of the Shahejie Formation $\left(\mathrm{Es}_{4}\right)$ was deeply buried, and the temperature might exceed $210{ }^{\circ} \mathrm{C}$ in its maximum depth. According to the experiment carried out by Luo et al. (2008), crude oil would crack into gases when the temperature exceeded $160{ }^{\circ} \mathrm{C}$. Compared with kerogen thermal degradation gas with the similar maturity, $\delta^{13} \mathrm{C}_{1}$ and $\delta^{13} \mathrm{C}_{2}$ of oil-cracking gas were fairly light and, respectively, ranged from $-48.4 \%$ to $-50.4 \%$ and from $-33 \%$ to $-34 \%$ (Song et al. 2009; Tian et al. 2009).

Based on comparison of light hydrocarbon compounds in oil-cracking gas and kerogen thermal degradation gas, $\mathrm{Hu}$ et al. (2005) put forward that $\mathrm{MCC}_{6} / n \mathrm{C}_{7}$ and (2$\left.\mathrm{MC}_{6}+3-\mathrm{MC}_{6}\right) / n \mathrm{C}_{6}$ of oil-cracking gas were higher than those of kerogen thermal degradation gases $\left(\mathrm{MCC}_{6}\right.$ means methylcyclohexane, 2- $\mathrm{MC}_{6}$ means 2-methylhexane, 3- $\mathrm{MC}_{6}$ means 3-methylhexane, $n \mathrm{C}_{7}$ means $n$-heptane, $n \mathrm{C}_{6}$ means $n$-hexane). Based on simulation experiments, Wang (2005) discovered that there were differences in $\mathrm{MCC}_{6} /$ $\mathrm{CC}_{6}, \quad \mathrm{MCC}_{6} / n \mathrm{C}_{7}$, and $\left(2-\mathrm{MC}_{6}+3-\mathrm{MC}_{6}\right) / n \mathrm{C}_{6}$ between these two kinds of highly mature oil-type gases $\left(\mathrm{CC}_{6}\right.$ means cyclohexane). The content of thermally stable compounds in kerogen thermal degradation gas was higher than that in oil-cracking gas. In the Jiyang Depression, 
Table 4 Geochemical characteristics of typical mature oil-type gases in the Jiyang Depression

\begin{tabular}{|c|c|c|c|c|c|c|c|c|c|c|c|}
\hline Area & Formation & Well & $\begin{array}{l}\text { Depth, } \\
\mathrm{m}\end{array}$ & $\begin{array}{l}\delta^{13} \mathrm{C}_{1}, \\
\%(\mathrm{PDB})\end{array}$ & $\begin{array}{l}\delta^{13} \mathrm{C}_{2}, \% o \\
(\mathrm{PDB})\end{array}$ & $\begin{array}{l}\delta^{13} \mathrm{C}_{3}, \% \\
(\mathrm{PDB})\end{array}$ & $\begin{array}{l}\delta^{13} \mathrm{C}_{4}, \% \\
\text { (PDB) }\end{array}$ & $\begin{array}{l}\mathrm{CH}_{4}, \\
\%\end{array}$ & $\begin{array}{l}\mathrm{C}_{2+}, \\
\%\end{array}$ & $\mathrm{~N}_{2}, \%$ & $\begin{array}{l}\mathrm{CO}_{2} \\
\%\end{array}$ \\
\hline \multirow{3}{*}{$\begin{array}{c}\text { Chengdao } \\
\text { Oilfield }\end{array}$} & $\mathrm{N}$ & Chengbs19 & 1308.2 & -53.9 & -36.2 & -34.9 & -32.1 & 98.03 & 1.2 & 0.37 & 0.2 \\
\hline & $\mathrm{E}$ & Chengb12 & 2144.5 & -38.0 & -28.3 & -27.8 & -27.1 & 60.63 & 38.79 & 0.62 & 0.63 \\
\hline & $\mathrm{Pz}$ & Chengb242 & 2936.6 & -45.7 & -31.2 & -28.9 & -28.1 & 70.97 & 26.37 & 0.29 & 2.26 \\
\hline Linpan Oilfield & $\mathrm{N}$ & Lin2-6 & 1582.8 & -44.5 & -32.5 & -26.7 & -27.7 & 96.6 & 2.728 & 0.594 & 0.177 \\
\hline $\begin{array}{l}\text { Yanjia Gas } \\
\text { Field }\end{array}$ & $\mathrm{E}$ & Yan22 & 1573.0 & -47.4 & -33.5 & -29.2 & -27.7 & 70.77 & 25.39 & 0.39 & 3.45 \\
\hline $\begin{array}{l}\text { Dongfenggang } \\
\text { Oilfield }\end{array}$ & $\mathrm{E}$ & Che57 & 4067.0 & -44.2 & & & & 81.8 & 11.86 & 0.06 & 6.28 \\
\hline \multirow{3}{*}{$\begin{array}{r}\text { Shengtuo } \\
\text { Oilfield }\end{array}$} & $\mathrm{E}$ & Ning3 & 1805.6 & -45.8 & -35.6 & -29.4 & -28.4 & 83.79 & 13.98 & 0 & 0.4 \\
\hline & $\mathrm{E}$ & Tuo113 & 1948.6 & -53.8 & & & & 91.86 & 6.18 & 0 & 0.34 \\
\hline & $\mathrm{E}$ & Tuo165 & 3391.1 & -50.3 & -35.1 & -30.5 & -29.0 & 65.95 & 19.02 & 2.79 & 12.24 \\
\hline Gubei Oilfield & $\mathrm{E}$ & Gub1 & 2138.5 & -47.1 & & & & 75.36 & 17.03 & 0.77 & 6.84 \\
\hline \multirow[t]{4}{*}{ Bonan Oilfield } & $\mathrm{E}$ & Xiny12 & 2454.9 & -52.3 & -33 & -31.2 & -29.8 & 74.78 & 20.5 & 0 & 4.3 \\
\hline & $\mathrm{E}$ & Yi37 & 3220.3 & -45.6 & -31.7 & -32.9 & -28.3 & 66.2 & 22.45 & 0 & 9.55 \\
\hline & $\mathrm{E}$ & Yi170 & 3817.6 & -52.6 & -31.2 & -27.3 & -27.2 & 84.44 & 12.4 & 0.14 & 2.72 \\
\hline & $\mathrm{E}$ & Bos4 & 3911.5 & -52.7 & -30.8 & -28.2 & -28.1 & 83.38 & 14.59 & 1.53 & 1.4 \\
\hline Gudong Oilfield & $\mathrm{E}$ & Gud9 & 2506.4 & -48.7 & -27.4 & -27.3 & -25.6 & 60.05 & 20.99 & 24 & 2.52 \\
\hline Guangli Oilfield & $\mathrm{E}$ & Lai10 & 2665.1 & -50.6 & & & & 81.35 & 15.39 & 0 & 0.46 \\
\hline \multirow{2}{*}{$\begin{array}{l}\text { Liangjialou } \\
\text { Oilfield }\end{array}$} & $\mathrm{E}$ & Liang60 & 2844.8 & -52.3 & & & & 73.12 & 20.23 & 0 & 3.61 \\
\hline & $\mathrm{E}$ & Ling35 & 3119.9 & -50.8 & & & & 89.84 & 5.93 & 0 & 1.28 \\
\hline Lijin Oilfield & $\mathrm{E}$ & Li54 & 2904.3 & -49.5 & & & & 70.11 & 22.23 & 0 & 5.93 \\
\hline \multirow[t]{2}{*}{ Xianhe Oilfield } & $\mathrm{E}$ & Niu23 & 3289.8 & -52.1 & & & & 73.2 & 20.13 & 0 & 4.05 \\
\hline & $\mathrm{E}$ & Wang53 & 3389.0 & -50.4 & & & & 67.63 & 23.94 & 0 & 4.99 \\
\hline $\begin{array}{l}\text { Dawangzhuang } \\
\text { Oilfield }\end{array}$ & $\mathrm{O}$ & Dag23 & 1738.3 & -44.4 & & & & 90.18 & 7.23 & 0 & 2.04 \\
\hline $\begin{array}{l}\text { Chengdong } \\
\text { Oilfield }\end{array}$ & $\mathrm{P}$ & Chengk1 & 2588.0 & -51.5 & -34.1 & -31.7 & -29.8 & 73.92 & 25.53 & 0.18 & 0.71 \\
\hline $\begin{array}{l}\text { Yong'anzhen } \\
\text { Oilfield }\end{array}$ & $\mathrm{E}$ & Yong12-21 & & -47.6 & -39.9 & -31.3 & -28.5 & 98.55 & 1.28 & 1.109 & 0.663 \\
\hline \multirow{11}{*}{$\begin{array}{r}\text { Zhuangxi } \\
\text { Oilfield }\end{array}$} & $\mathrm{E}$ & Zhuang202 & 2644.5 & -51.6 & -34.9 & -31.7 & -29.4 & 86.22 & 7.49 & 0 & 1.13 \\
\hline & $\mathrm{E}$ & Zhuang50 & 3228.2 & -49.7 & -33.5 & -30.1 & -28.2 & 89.44 & 7.47 & 0 & 1.73 \\
\hline & $\mathrm{E}$ & Zhuang74 & 3634.5 & -47.6 & -33.3 & -28.9 & -27.5 & 68.44 & 23.49 & 0 & 4.81 \\
\hline & $\mathrm{O}$ & Zhuangg10 & 3627.2 & -44.1 & & & & 63.74 & 28.75 & 0 & 3.56 \\
\hline & $\mathrm{O}$ & Zhuangg21 & 3929.1 & -42.4 & -27.9 & -27.7 & -26.4 & 67.15 & 25.73 & 0 & 3.13 \\
\hline & $\mathrm{O}$ & Zhuangg4 & 4013.5 & -45.4 & & & & 77.5 & 16.97 & 0 & 4.55 \\
\hline & $\in-A n z$ & Zhuangg25 & 4277.6 & -43.2 & -29.7 & -26.3 & -27.7 & 71.34 & 25.48 & 0 & 1.36 \\
\hline & $\mathrm{O}$ & Zhuangg14 & 4318.5 & -46.1 & -32.0 & -29.6 & & 76.77 & 13.21 & 0 & 9.24 \\
\hline & $\mathrm{O}$ & Zhuangg13 & 4367.5 & -42.2 & -29.5 & -28.1 & -27.2 & 69.54 & 27.75 & 0 & 1.87 \\
\hline & $\mathrm{O}$ & Zhuangg18 & 4582.4 & -44.4 & & & & 71.18 & 24.65 & 0.59 & 3.08 \\
\hline & $\epsilon$ & Zhuangg17 & 4886.2 & -45.8 & -31.9 & -29.2 & -28.5 & 85.99 & 10.25 & 0.58 & 3.09 \\
\hline
\end{tabular}

$\mathrm{MCC}_{6} / n \mathrm{C}_{7}$ of oil-cracking gas was higher than 1.0 , (2$\left.\mathrm{MC}_{6}+3-\mathrm{MC}_{6}\right) / n \mathrm{C}_{6}$ of oil-cracking gas was higher than 0.4 , which were higher than those of kerogen thermal degradation gas and mature oil-type gas, while $\mathrm{MCC}_{6} / n \mathrm{C}_{7}$ of oil-cracking gas was less than 0.8 which was lower than that of kerogen thermal degradation gas and mature oiltype gas (Fig. 7).

\subsection{Coal-type gas}

Coal-type gas is defined as natural gas generated by coal or humic kerogen due to biochemical and chemical action. Coal-type gas discovered in the Jiyang Depression was mainly developed in the Paleozoic Ordovician and Carboniferous-Permian in the Gubei buried hill belt, the 


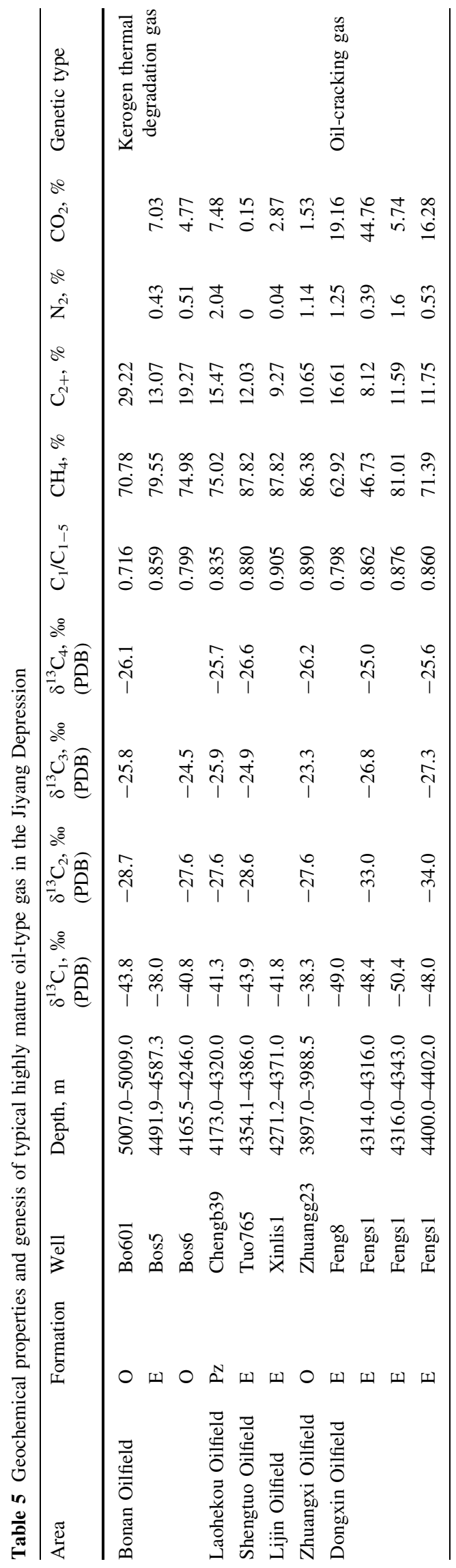

fourth member of the Shahejie Formation in the Bonan deep sag, and the Shahejie Formation in the Qudi Oilfield in the Huimin Sag. Coal-type gas in the Gubei buried hill and Qudi Oilfield was generated by coal and humic kerogen in the Shanxi Formation and Taiyuan Formation in Carboniferous-Permian, while that in the Bonan Sag (Well Yi115 and Yi121) was generated by humic kerogen in the upper part of $\mathrm{Es}_{4}$.

The methane content of coal-type gas ranged from $75 \%$ to $92 \%$, and the heavy hydrocarbon content varied greatly from $0.51 \%$ to $19.5 \% . \mathrm{C}_{1} / \mathrm{C}_{1-5}$ ranged from 0.8 to 0.99 and the value of most samples exceeded $0.9 . \mathrm{C}_{1} / \mathrm{C}_{1-5}$ of coal-type gas is usually higher than that of oil-type gas with a similar maturity. $\delta^{13} \mathrm{C}_{1}$ of coal-type gas in the Jiyang Depression ranged from $-32.6 \%$ to $-41.0 \%, \quad \delta^{13} \mathrm{C}_{2}$ ranged from $-22.0 \%$ to $-27.6 \%$ (Table 6 ). There was a slight reversal in $\delta^{13} \mathrm{C}_{3}$ and $\delta^{13} \mathrm{C}_{4}$ and this might be caused by mixing with oil-type gas. It is pointed out that $\delta^{13} \mathrm{C}_{2}$ of coal-type gas in China is usually higher than $-28 \%$ (Song et al. 2012; Dai et al. 2012; Wang et al. 2010), and in the Jiyang Depression, the carbon isotope ratios of coal-type gas are located in the "I" area of the "V" shaped $\delta^{13} \mathrm{C}_{1}$ $\delta^{13} \mathrm{C}_{2}-\delta^{13} \mathrm{C}_{3}$ template (Fig. 6).

$\mathrm{C}_{7}$ light hydrocarbon information can also be used to distinguish coal-type gas from oil-type gas. The $\mathrm{C}_{7}$ system is composed of three kinds of compounds: normal heptane $\left(n \mathrm{C}_{7}\right)$, methylcyclohexane $\left(\mathrm{MCC}_{6}\right)$, and multi-structured dimethylcyclopentane $\left(\sum \mathrm{DMCC}_{5}\right)$. $\mathrm{MCC}_{6}$ mainly came from higher plants and was a major component of $\mathrm{C}_{7}$ system in coal-type gas, and $\sum \mathrm{DMCC}_{5}$ mainly came from aquatic organisms and was a major component of $\mathrm{C}_{7}$ system in oil-type gas (Song and Zhang 2004).

As shown in Fig. 8, coal-type gas differed significantly from oil-type gas. $\mathrm{MCC}_{6} / \sum \mathrm{C}_{7}$ of the coal-type gas exceeded $50 \%$, while $\sum \mathrm{DMCC}_{5} / \sum \mathrm{C}_{7}$ was less than $40 \%$; as for oil-type gas, $n \mathrm{C}_{7} / \sum \mathrm{C}_{7}$ exceeded $30 \%$, $\mathrm{MCC}_{6} / \sum \mathrm{C}_{7}$ ranged from 20 to $40 \%$.

\section{Secondary changes of natural gas}

Most shallow gas in the Jiyang Depression was originally dissolved gas that escaped from oil when temperature and pressure changed due to migration of oil along faults or sand bodies. This kind of natural gas was located in the "d" area (oil-associated gas) of " ${ }^{13} \mathrm{C}_{\mathrm{CH}_{4}}-\mathrm{C}_{1} /\left(\mathrm{C}_{2}+\mathrm{C}_{3}\right)$ template" in Fig. 5, and in "II" area of "V" shaped " $\delta{ }^{13} \mathrm{C}_{1}-$ $\delta^{13} \mathrm{C}_{2}-\delta^{13} \mathrm{C}_{3}$ template" in Fig. 6, and was typical mature oil-type gas.

There is a kind of shallow gas whose hydrocarbon carbon isotope ratios are similar to mature oil-type gas, but its heavy hydrocarbon content is extremely low, the methane content is very high ( $>95 \%), \mathrm{C}_{1} / \mathrm{C}_{1-5}$ is higher than 0.95 , 
Table 6 Geochemical properties of typical coal-type gas in the Jiyang Depression

\begin{tabular}{|c|c|c|c|c|c|c|c|c|c|c|c|}
\hline Area & Formation & Well & Depth, m & $\begin{array}{l}\delta^{13} \mathrm{C}_{1}, \% \\
(\mathrm{PDB})\end{array}$ & $\begin{array}{l}\delta^{13} \mathrm{C}_{2}, \% 0 \\
(\mathrm{PDB})\end{array}$ & $\begin{array}{l}\delta^{13} \mathrm{C}_{3}, \% \\
(\mathrm{PDB})\end{array}$ & $\begin{array}{l}\delta^{13} \mathrm{C}_{4}, \% 0 \\
(\mathrm{PDB})\end{array}$ & $\mathrm{CH}_{4}, \%$ & $\mathrm{C}_{2+}, \%$ & $\mathrm{~N}_{2}, \%$ & $\mathrm{CO}_{2}, \%$ \\
\hline \multirow[t]{9}{*}{ Gudao Oilfield } & $\mathrm{C}-\mathrm{P}$ & Bo93 & $3230.0-3249.4$ & -38.1 & -22.7 & -21.25 & -21.8 & 88.99 & 7.81 & & 2.29 \\
\hline & $\mathrm{O}$ & BoG4 & $4375.0-4460.0$ & -38.2 & -24.9 & -22.5 & -23.6 & 85.32 & 10.02 & 0 & 4.66 \\
\hline & $\mathrm{O}$ & BoG403 & $3850.5-3889.3$ & -37.1 & -24.2 & -22.0 & -23.5 & 85.16 & 8.68 & 0.83 & 5.31 \\
\hline & Es & BoS3 & $4450.1-4472.4$ & -39.1 & -26.7 & -23.4 & -23.9 & 83.15 & 10.8 & 0.73 & 5.05 \\
\hline & $\mathrm{P}$ & GBG1 & $4020.6-4139.5$ & -35.9 & -23.1 & -21.2 & -21.2 & 88.44 & 6.48 & 0.55 & 4.54 \\
\hline & $\mathrm{C}-\mathrm{P}$ & GBG1 & $4120.6-4139.0$ & -35.8 & -22.9 & -21.5 & -20.8 & 82.52 & 10.09 & 0.74 & 6.66 \\
\hline & $\mathrm{C}-\mathrm{P}$ & GBG2 & $3689.0-3731.0$ & -41.0 & -25.8 & -23.6 & -23.6 & 75.87 & 19.52 & 0.96 & 3.65 \\
\hline & $\mathrm{Mz}$ & Yi132 & $3374.0-3387.0$ & -37.0 & -25.3 & -25.0 & -25.5 & 87.01 & 7.9 & 1.98 & 2.18 \\
\hline & $\mathrm{P}$ & Yi155 & $4696.3-4706.7$ & -32.7 & -22.0 & -21.5 & -21.0 & 87.64 & 4.85 & & 6.64 \\
\hline \multirow[t]{3}{*}{ Bonan Oilfield } & Es & Yi115 & $5110.4-5164.4$ & -35.9 & -24.9 & -21.8 & & 80.18 & 0.51 & 0.05 & 19.27 \\
\hline & Es & Yi121 & $4426.1-4438.4$ & -38.0 & -22.0 & -19.3 & -20.6 & 91.36 & 1.46 & 0 & 7.09 \\
\hline & $\mathrm{O}$ & BoS6 & $4165.5-4246.0$ & -40.8 & -27.6 & -24.5 & & 74.98 & 19.27 & 0.51 & 4.77 \\
\hline Qudi Oilfield & Es & QuG1 & $1514.0-1520.0$ & -32.6 & -23.9 & -20.3 & -20.2 & 77.25 & 9.53 & 11.99 & 0.93 \\
\hline
\end{tabular}
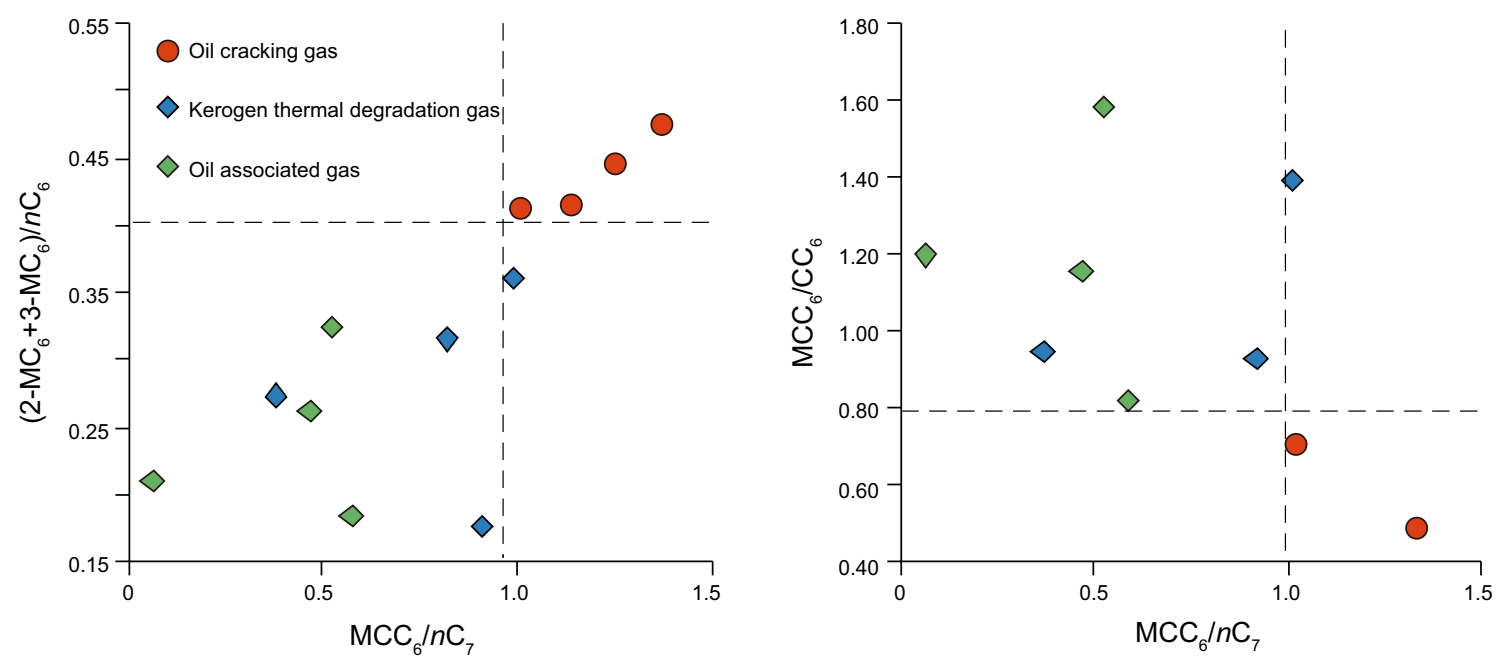

Fig. 7 Light hydrocarbon property differences between oil cracking gas and kerogen thermal degradation gas

and is located above the " $\mathrm{d}$ " area of the " ${ }^{13} \mathrm{C}_{\mathrm{CH} 4}-\mathrm{C}_{1}$ / $\left(\mathrm{C}_{2}+\mathrm{C}_{3}\right)$ template" (Table 7; Fig. 5). Such characteristics are caused by composition changes during long distance migration of natural gas. Gas migration experiments in porous sandstone core samples indicated that, with increasing migration distance, the methane content tended to increase while the heavy hydrocarbon content $\left(\mathrm{C}_{2+}\right)$ decreased correspondingly. Furthermore, the carbon isotopes of hydrocarbon differentiated slightly and this means that carbon isotopes became lighter with an increase of migration distance (variation range usually less than $-2 \%$ ). Therefore, it is believed that this kind of natural gas with a high content of methane was dissolved gas that escaped from oil after long-distance migration.

There is another kind of shallow gas whose methane carbon isotope ratios are heavier than those of mature oiltype gas, and $\delta^{13} \mathrm{C}_{2}$ and $\delta^{13} \mathrm{C}_{3}$ are extremely heavy. $\delta^{13} \mathrm{C}_{3}$ of

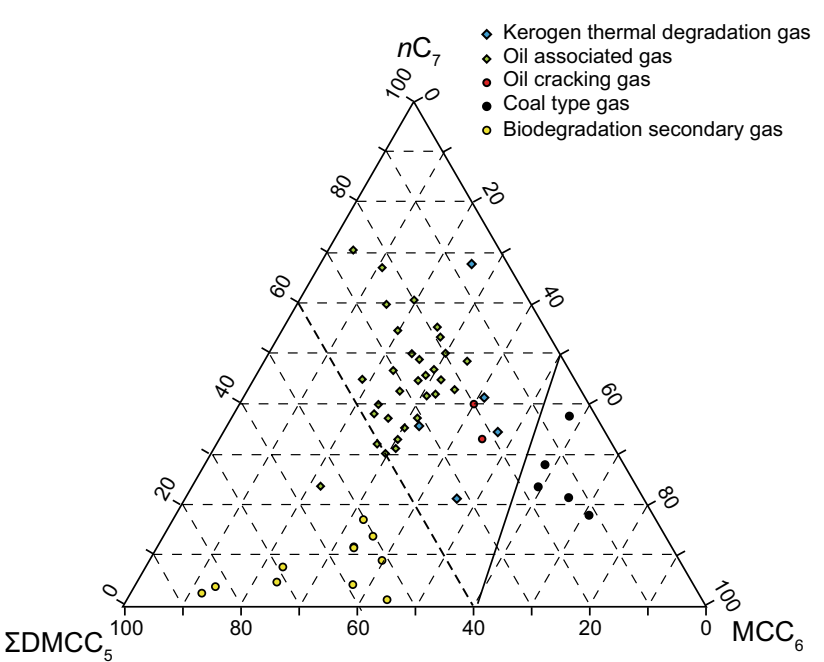

Fig. 8 Triangular template of $\mathrm{C}_{7}$ light hydrocarbon in different kinds of natural gases in the Jiyang Depression 


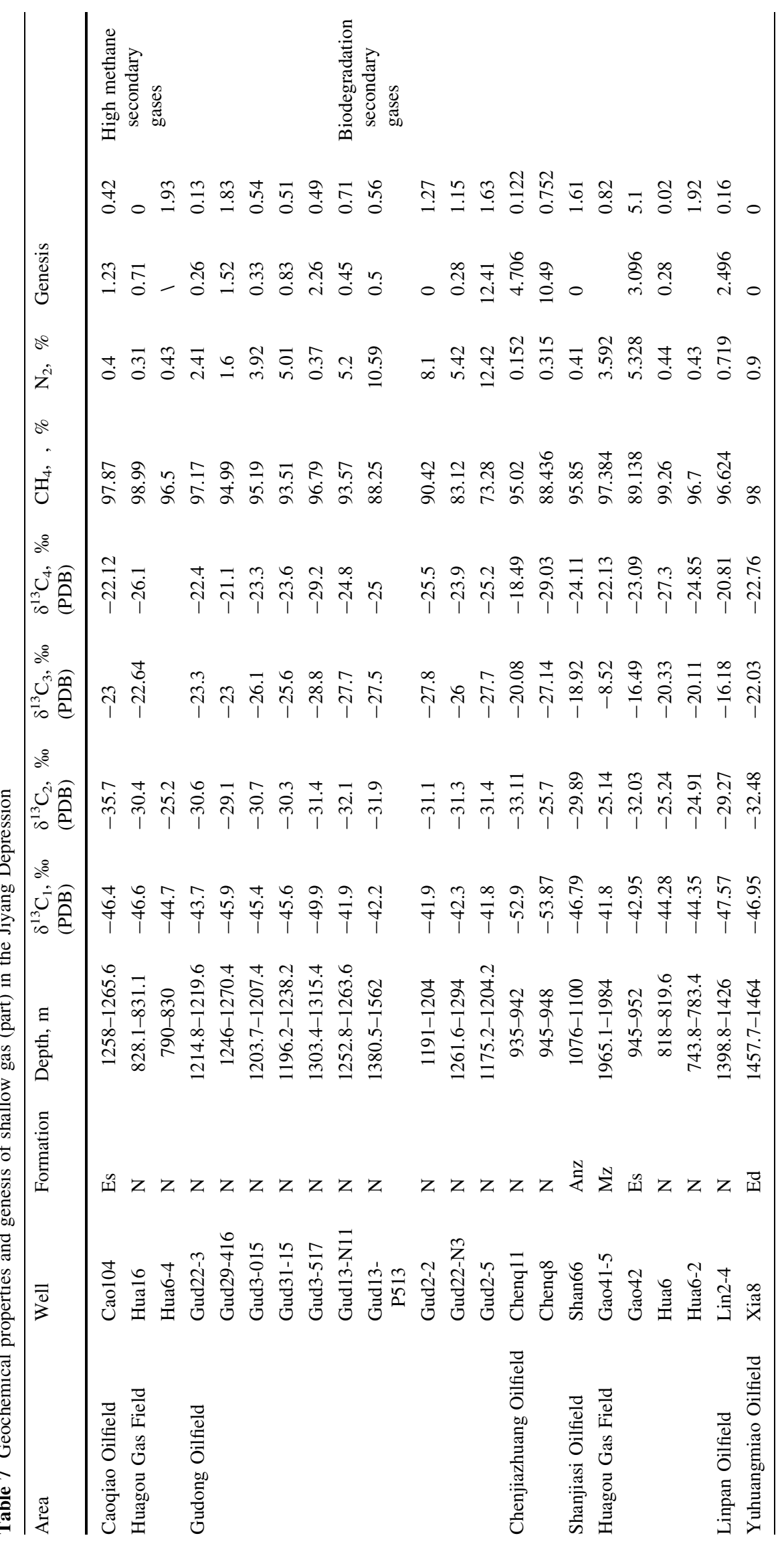


normal mature oil-type gas ranged from $-26 \%$ to $-34 \%$, while $\delta^{13} \mathrm{C}_{3}$ of this kind of natural gas might as heavy as $-8.5 \%$. $\delta^{13} \mathrm{C}_{3}$ of most natural gas ranged from $-8 \%$ to $-22 \%$, and carbon isotope ratios of light hydrocarbons arranged in the order of $\delta^{13} \mathrm{C}_{1}<\delta^{13} \mathrm{C}_{2}<\delta^{13} \mathrm{C}_{3}>\delta^{13} \mathrm{C}_{4}$. $\delta^{13} \mathrm{C}_{1}$ of some samples was about $2 \%$ o $-7 \%$ heavier than that of mature oil-type gas. Take the Gudong Oilfield as an example, $\delta^{13} \mathrm{C}_{1}$ of mature oil-type gas (Well Gud3-517) was about $-49.9 \%$ o, $\delta^{13} \mathrm{C}_{2}$ was about $-31.4 \%$, but $\delta^{13} \mathrm{C}_{1}$ and $\delta^{13} \mathrm{C}_{2}$ of the sample from the same horizon and similar depth (Gud2-2) were, respectively, $-41.9 \%$ and $-31.1 \%$, that is to say $\delta^{13} \mathrm{C}_{1}$ was about $8 \%$ heavier than that in Well Gud3517.

Analysis indicated that the main reason that caused abnormal carbon isotope ratios was biodegradation. James and Burns (1984) analyzed the carbon isotope ratios of light hydrocarbons of biodegradation natural gases in Australia and Canada, and discovered that $\delta^{13} \mathrm{C}_{3}$ was abnormally heavy. They deduced that since propane is soluble in water, it is readily biodegradable. Secondary biodegradation shallow gas in the Jiyang Depression exhibited the similar characteristics.

Stahl (1980) carried out bacterial degradation experiments, and pointed out that long-chained paraffin hydrocarbon is more easily degradable than short-chained ones, and normal paraffin hydrocarbon is more easily degradable than isomeric ones. As shown in Fig. $8, n \mathrm{C}_{7} / \sum \mathrm{C}_{7}$ of biodegradation shallow gas was less than $20 \%$, and was obviously less than that of mature oil-type gas.

Leythaeuser et al. (1979) studied biodegradation of oil using light hydrocarbon data, and summarized typical characteristics: the content of normal paraffin hydrocarbon was low, while the contents of isomeric ones (such as 3,3$\mathrm{DMC}_{5} ; 2,3,3-\mathrm{TMC}_{4} ; 2,2-\mathrm{DMC}_{5} ; 2,4-\mathrm{DMC}_{5}$ and 2,2$\mathrm{DMC}_{4}$ ) were high (DMC 5 means dimethylpentane, $\mathrm{TMC}_{4}$ means triptane, $\mathrm{DMC}_{4}$ means dimethylbutane). Based on analysis of light hydrocarbons in shallow gas in the Jiyang Depression, Zhang (1991) pointed out that the relationship between $2,4-\mathrm{DMC}_{5} / n \mathrm{C}_{6}$ and the heptane index can be used to distinguish biodegradation oil-type gas from other oil-type gases. As shown in Fig. 9, the value of 2,4$\mathrm{DMC}_{5} / n \mathrm{C}_{6}$ for biodegradation gas was usually higher than 0.5 , and the heptane index was usually less than 5; in contrast, the heptane index usually ranged from 20 to 50 , and $2,4-\mathrm{DMC}_{5} / n \mathrm{C}_{6}$ for other oil-type gases was less than 0.1 .

\section{Identification factors}

Based on discussion above, the identification factors for different kinds of natural gases are summarized in Table 8 ,

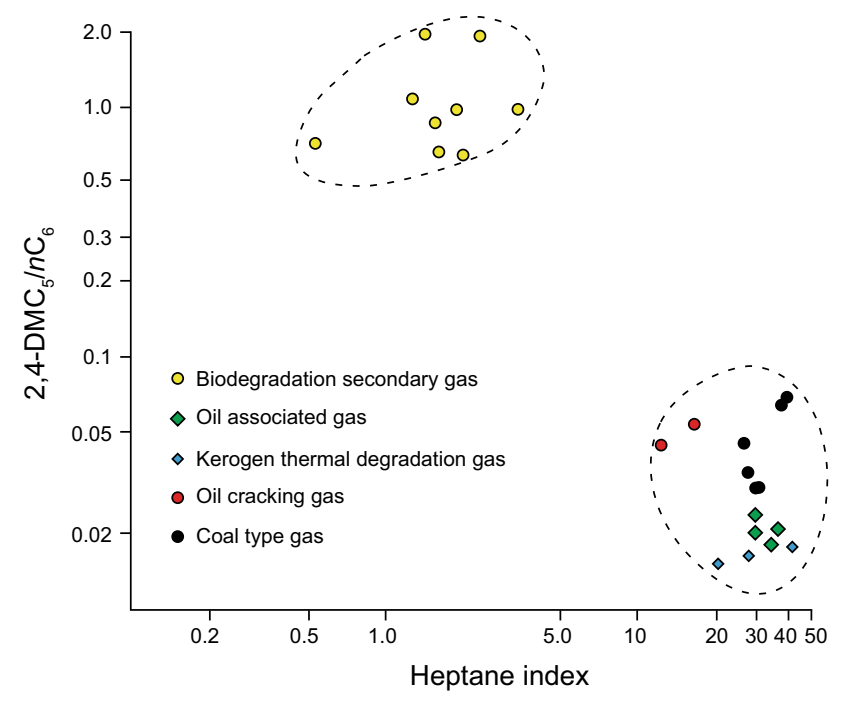

Fig. $92,4-\mathrm{DMC}_{5} / n \mathrm{C}_{6}$-heptane index template of natural gases in the Jiyang Depression (Zhang 1991)

Heptane index $=100 \times n \mathrm{C}_{7} /\left(\mathrm{CC}_{6}+2-\mathrm{MC}_{6}\right.$

$$
\begin{aligned}
& +2,3-\mathrm{DMC}_{5}+1,1-\mathrm{DMC}_{5} \\
& +3-\mathrm{MC}_{6}+1, \mathrm{C}, 3-\mathrm{DMCC}_{5} \\
& \left.+n \mathrm{C}_{7}+\mathrm{MCC}_{6}\right)
\end{aligned}
$$

and with the help of gas compositions, carbon isotope ratios of paraffin hydrocarbon and $\mathrm{CO}_{2}$, and light hydrocarbon index, it is feasible to identify the genesis of natural gases in the Jiyang Depression.

Take mature oil-type gas as reference, biogas has a high methane content, and $\delta^{13} \mathrm{C}_{1}$ was less than $-55 \%$; highly mature oil-type gases are divided into kerogen thermal degradation gas and oil-cracking gas. They both have a high value of $\mathrm{C}_{1} / \mathrm{C}_{1-5}$ and heavy methane carbon isotope ratios, and they can be distinguished by the $\left(2-\mathrm{MC}_{6}+3-\mathrm{MC}_{6}\right) /$ $n \mathrm{C}_{6}-\mathrm{MCC}_{6} / n \mathrm{C}_{7}$ template. Ethane carbon isotope ratios of coal-type gas in the Jiyang Depression are usually higher than $-28 \%$ and the compositions of $\mathrm{C}_{7}$ can be used to effectively distinguish coal-type gas from oil-type gas.

Heavy hydrocarbons usually reduce in the process of gas migration. The $\mathrm{C}_{1} / \mathrm{C}_{2+3}$ value of methane rich secondary gas might exceed 280, and its carbon isotope compositions and light hydrocarbon compositions are similar to those of mature oil-type gas. Secondary biodegradation gas is featured by heavy carbon isotope ratios of $\delta^{13} \mathrm{C}_{1}$ or $\delta^{13} \mathrm{C}_{3}$, and light hydrocarbon isotope ratios arrange in the order of $\delta^{13} C_{1}<\delta{ }^{13} C_{2}<\delta{ }^{13} C_{3}>\delta{ }^{13} C_{4}$. Influenced by biodegradation, the normal paraffin hydrocarbon content is low. The triangular template of $\mathrm{C}_{7}$ and $2,4-\mathrm{DMC}_{5} / n \mathrm{C}_{6}$-heptane index template can be used to distinguish the secondary biodegradation gas from other natural gases. 


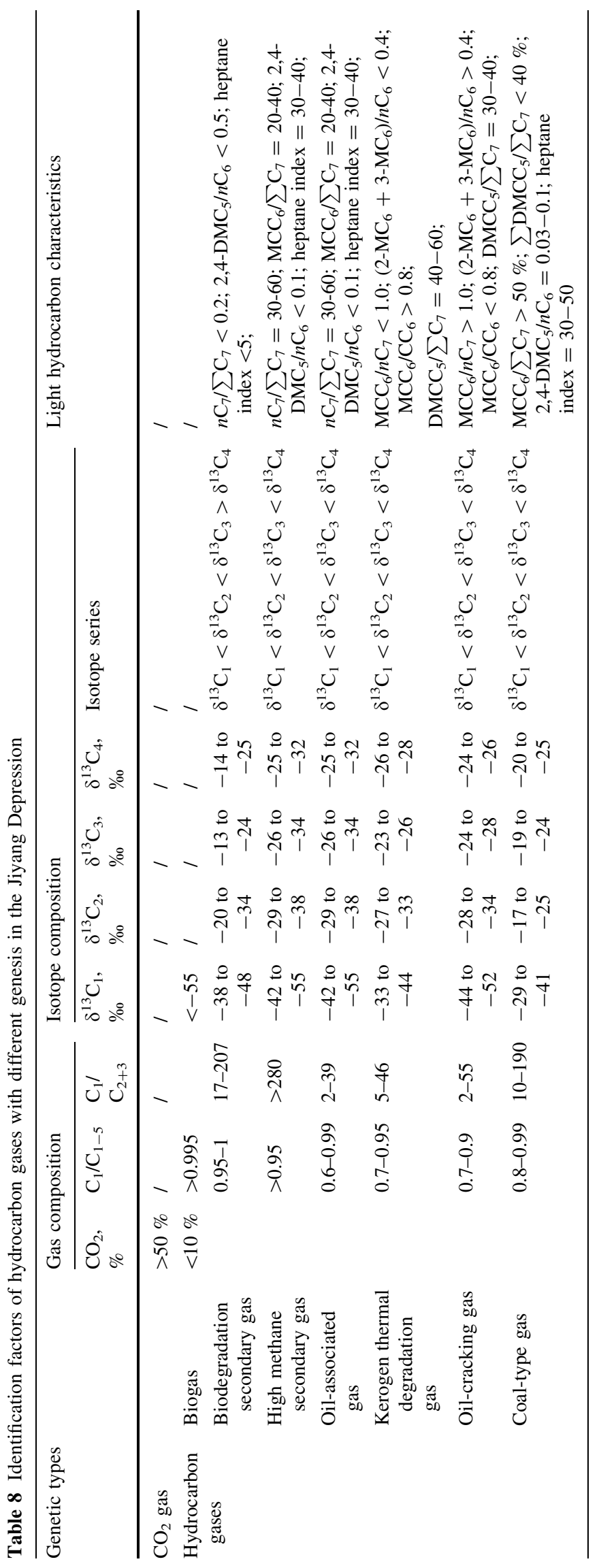




\section{Conclusions}

1) Based on analysis of gases compositions, carbon isotope ratios, light hydrocarbon properties, combined with geological analysis, natural gases in the Jiyang Depression were classified into two categories namely hydrocarbon gas and abiogenic gas. The abiogenic gas was mainly magmatogenic or mantle derived $\mathrm{CO}_{2}$. Hydrocarbon gases were further divided into coal-type gas, oil-type gas, and biogas according to the kerogen types and formation mechanisms. The oil-type gases were divided into mature oil-type gas (oil-associated gas), highly mature oil-type gas. Highly mature oil-type gases were subdivided into oil-cracking gas and kerogen thermal degradation gas.

2) Analysis results showed that shallow gases (buried less than $1,500 \mathrm{~m}$ ) are mainly mature oil-type gases, secondary gas is rich in methane after chromatographic separation during migration and secondary mature oil-type gas after biodegradation is featured by rich in ${ }^{13} \mathrm{C}$ in methane and ethane. Meanwhile, biogas is another kind of shallow gas. The genesis of middle gases buried in the depth of $1,500-3,500 \mathrm{~m}$ was simple and was dominated by mature oil-type gases. Deep gases buried in the depth of 3,500-5,500 m were usually kerogen thermal degradation gas, oilcracking gas, and coal-type gas.

3) Due to chromatographic effects, the methane content increases and heavy hydrocarbons decrease during the progress of migration. Secondary biodegradation gas was featured by heavy carbon isotope ratios of $\delta^{13} \mathrm{C}_{1}$ or $\delta^{13} \mathrm{C}_{3}$, and light hydrocarbon isotope ratios arranged in the order of $\delta^{13} \mathrm{C}_{1}<\delta^{13} \mathrm{C}_{2}<\delta^{13} \mathrm{C}_{3}>$ $\delta^{13} \mathrm{C}_{4}$. Influenced by biodegradation, the normal paraffin hydrocarbon content was low. Triangular template of $\mathrm{C}_{7}$ and $2,4-\mathrm{DMC}_{5} / n \mathrm{C}_{6}$-heptane index template can be used to distinguish secondary biodegradation gas from other natural gases.

Open Access This article is distributed under the terms of the Creative Commons Attribution License which permits any use, distribution, and reproduction in any medium, provided the original author(s) and the source are credited.

\section{References}

Burruss RC, Laughrey CD. Carbon and hydrogen isotopic reversals in deep basin gas: evidence for limits to the stability of hydrocarbons. Org Geochem. 2010;41(12):1285-96.

Chen ZH, Zhang SC, Zha M. Geochemical evolution during the cracking of crude oil into gas under different pressure systems. Sci China: Earth Sci. 2014;57(3):480-90.
Dai JX. The carbon and hydrogen isotope characteristics and identification of different kinds of natural gases. Nat Gas Geosci. 1993;2:1-40 (in Chinese).

Dai JX, Ni YY, Zou CN. Stable carbon and hydrogen isotopes of natural gases sourced from the Xujiahe Formation in the Sichuan Basin, China. Org Geochem. 2012;43:103-11.

Gao Y, Jin Q, Zhu GY. Genetic types and distribution of shallowburied natural gases. Pet Sci. 2010;7(3):347-54.

Gao Y, Jin Q, Shuai YH, et al. Genetic types and accumulation conditions of biogas in Bohaiwan Basin. Nat Gas Geosci. 2011;22(3):407-14 (in Chinese).

Hu GY, Luo X, Li ZS, et al. Geochemical characteristics and origin of light hydrocarbons in biogenic gas. Sci China: Earth Sci. 2010;53(6):832-43

$\mathrm{Hu}$ GY, Xiao ZY, Luo X, et al. Light hydrocarbon composition difference between two kinds of cracked gases and its application. Nat Gas Ind. 2005;25(9):23-5 (in Chinese).

Hunt AG, Darrah TH, Poreda RJ. Determining the source and genetic fingerprint of natural gases using noble gas geochemistry: A northern Appalachian Basin case study. AAPG Bull. 2012;96(10):1785-811.

James AT, Burns BJ. Microbial alteration of subsurface natural gas accumulations. AAPG Bull. 1984;68(8):957-60.

Leythaeuser D, Schaefer RG, Cornford C, et al. Generation and migration of light hydrocarbons $\left(\mathrm{C}_{2}-\mathrm{C}_{7}\right)$ in sedimentary basins. Org Geochem. 1979;1(4):191-204.

Li J, Hu GY, Zhang Y, et al. Study and application of carbon isotope fractionation during the reduction process from $\mathrm{CO}_{2}$ to $\mathrm{CH}_{4}$. Earth Sci Front. 2008;15(5):357-63 (in Chinese).

Li PL, Jin ZJ, Zhang SW, et al. The present research status and progress of petroleum exploration in the Jiyang Depression. Pet Explor Dev. 2003;30(3):1-4 (in Chinese).

Lin HX, Cheng FQ, Jin Q. Fractionation mechanism of natural gas components and isotopic compositions and sample analysis. Nat Gas Geosci. 2011;22(2):195-200 (in Chinese).

Lu SF, Li JJ, Xue HT, et al. Chemical kinetics of carbon isotope fractionation of oil-cracking methane and its initial application. J Jilin Univ (Earth Science Edition). 2006;36(5):825-9 (in Chinese).

Luo X, Wang YB, Li J, et al. Origin of gas in deep Jiyang Depression. Nat Gas Ind. 2008;28(9):13-6 (in Chinese).

Schoell M. The hydrogen and carbon isotopic composition of methane from natural gases of various origins. Geochim Cosmochim Acta. 1980;44(5):649-61.

Song GQ, Jin Q, Wang L, et al. Study on kinetics for generating natural gas of Shahejie Formation in deep-buried sags of Dongying Depression. Acta Petrolei Sinica. 2009;30(5):672-7 (in Chinese).

Song MS, Zhang XC. Discussion on deep gas geochemical characteristics and genesis of Bonan Sag, Jiyang Depression. Nat Gas Geosci. 2004;15(6):646-9 (in Chinese).

Song Y, Liu SB, Zhang Q, et al. Coalbed methane genesis, occurrence and accumulation in China. Pet Sci. 2012;9(3):269-80.

Stahl WJ. Compositional changes and ${ }^{13} \mathrm{C} /{ }^{12} \mathrm{C}$ fractionations during the degradation of hydrocarbons by bacteria. Geochim Cosmochim Acta. 1980;44(11):1903-7.

Sun ML, Chen JF, Liao YS. Helium isotopic characteristics, genesis of $\mathrm{CO}_{2}$ in natural gases and distribution of Tertiary magamatite in the Jiyang Depression. Geochimica. 1996;25(5):475-80 (in Chinese).

Tang DZ, Liu HX, Li XM, et al. Probe into deep-seated structural factors of abiogenic gas accumulation and storage in Jiyang Depression. Earth Sci: J China Univ Geosci. 2002;27(1):30-4 (in Chinese). 
Tian H, Xiao XM, Yang LG, et al. Pyrolysis of oil at high temperatures: gas potentials, chemical and carbon isotopic signatures. Chin Sci Bull. 2009;54(7):1217-24.

Wang G L. Accumulation conditions of natural gas in cratonic area, Tarim Basin. Ph.D. Thesis. Chengdu: Southwest Petroleum University. 2005. 43-47.

Wang P, Shen ZM, Liu SB, et al. Geochemical characteristics of noble gases in natural gas and their application in tracing natural gas migration in the middle part of the western Sichuan Depression, China. Pet Sci. 2013;10(3):327-35.

Wang YP, Dai JX, Zhao CY, et al. Genetic origin of Mesozoic natural gases in the Ordos Basin (China): comparison of carbon and hydrogen isotopes and pyrolytic results. Org Geochem. 2010;41(9):1045-8.
Zhang LY. Identifying criteria of natural gases in the Jiyang Depression. Pet Geol Exper. 1991;13(4):355-69 (in Chinese).

Zhao XZ, Jin Q, Jin FM, et al. Origin and accumulation of highmaturity oil and gas in deep parts of the Baxian Depression, Bohai Bay Basin, China. Pet Sci. 2013;10(3):303-13.

Zhou JL. Gas accumulation analysis of upper Paleozoic coal in the Jiyang Depression. J Earth Sci Environ. 2004;26(2):47-50 (in Chinese). 